溶接用シールドガスのキーポイント

\title{
溶接品質および作業性に及ぼす シールドガスの影響*
}

\author{
佐 藤 豊 幸** \\ Influence of Shielding Gases on Quality and \\ Efficiency in Gas Shielded Arc Welding* \\ by Toyoyuki SATOH \\ キーワード : シールドガス, スパッ夕, 溶滴移行, 靸性, 高速溶接, 作業環 \\ 境, トータルコスト
}

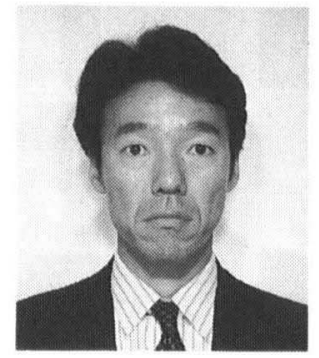

\section{1. は じめに}

近年の日本の製造業では, 人件費の高騰や熟練作業者 の不足といった問題を抱え, 作業の自動化・省力化等を 推進することによって能率を向上させることが急務であ る. 溶接の分野においてもこの傾向は顕著であり, 溶接

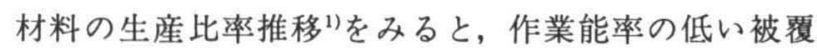
アーク溶接棒が年々減少し, 高能率なガスシールド溶接 用ワイヤの比率が増加している.この傾向は今後とも続 くと考えられ，シールドガスの果たす役割は更に重要性 を増していくと思われる.

ここで, 日本と欧米におけるマグ・ミグ溶接シールド ガスの使用比率 ${ }^{2}$ の比較を図 1 に示す。欧米では Ar を ベースとした混合ガスが主体であるのに対して，日本で は $\mathrm{CO}_{2}$ の比率が非常に高い. 更に日本で用いられる混合 ガスでは, $\mathrm{Ar}-20 \% \mathrm{CO}_{2}$ という単一組成が多く利用され ているのに比べて, 欧米では 30 種類以上の多様ながス 種3)が使い分けされている。

今回は, 沉用的なガスシールド溶接法を対象として, 用いられるシールドガスの違いによる溶接品質や作業性 への影響について事例を紹介しながら, シールドガス選 択のポイントについて述べる.

\section{2. 各種溶接品質に及ぼすシールドガスの影響}

\section{1 スパッタ発生量}

MAG 溶接におけるスパッタは極めて大きな問題であ

*原稿受付 平成 12 年 9 月 7 日

**正員 日本酸素的 Member, Nippon Sanso Corporation
ク，その発生量はシールドガス組成によって大きく影響 される。図 $2^{4}$ に MAG 溶接において $\mathrm{Ar}-\mathrm{CO}_{2}$ おび, $\mathrm{Ar}-\mathrm{O}_{2}$ を用いた場合のスパッ夕発生量を示す. $\mathrm{Ar}-\mathrm{CO}_{2}$ では, $\mathrm{CO}_{2}$ 濃度が高いほどスパッ夕の発生量が多く,

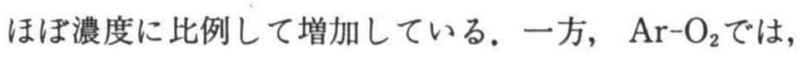
$\mathrm{O}_{2}$ 濃度とともにごくわずかに増加してはいるが, $\mathrm{Ar}-$ $\mathrm{CO}_{2}$ に比べて相対的にスパッ夕発生量が少ない.

スパッ夕の発生量については, その溶滴移行形態が最 も大きな因子であり，シールドガス組成によって溶滴移 行が大きく変化するために, 上記のような差異が生ず る. 高速度カメラにより観察した各ガス組成における溶 滴移行を図 $3^{4)}$ に示すが, 添加がス濃度の増加に伴い, ス トリーミング移行からプロジェクト移行へ, 更には反発 移行へと変化している様子がわかる.

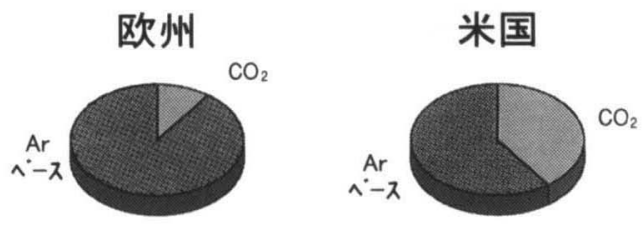

日本

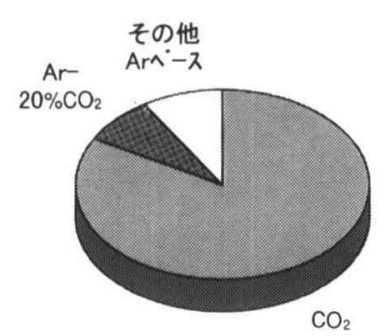

図 1 世界におけるマグ溶接シールドガス利用状況 (1990 1995 年) 


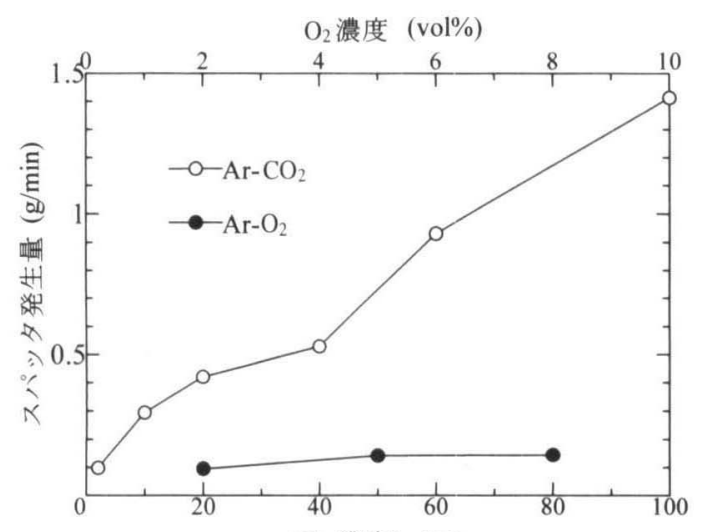

$\mathrm{CO}_{2}$ 濃度(vol\%)

図 2 スパッ夕発生量に及ばすシールドガスの影響 (YGW $15 \phi 1.2 \mathrm{~mm}, 250 \mathrm{~A}, 40 \mathrm{~cm} / \mathrm{min}$, 下向き ビードオン)

\begin{tabular}{|c|c|c|c|}
\hline $\begin{array}{c}\text { ガス組成 } \\
\left(\mathrm{Ar}-\mathrm{CO}_{2}\right)\end{array}$ & 溶滴移行 & $\begin{array}{l}\text { ガス組成 } \\
\left(\text { Ar- } \mathrm{O}_{2}\right)\end{array}$ & 溶滴移行 \\
\hline $\mathrm{Ar}-5 \% \mathrm{CO}_{2}$ & & Ar- $2 \% \mathrm{O}_{2}$ & \\
\hline $\mathrm{Ar}-10 \% \mathrm{CO}_{2}$ & & $\mathrm{Ar}-5 \% \mathrm{O}_{2}$ & \\
\hline $\mathrm{Ar}-20 \% \mathrm{CO}_{2}$ & & Ar- $10 \% \mathrm{O}_{2}$ & \\
\hline $\mathrm{Ar}-30 \% \mathrm{CO}_{2}$ & & & \\
\hline $100 \% \mathrm{CO}_{2}$ & & & \\
\hline 溶接条件 & \multicolumn{3}{|c|}{ YGW15 \$1.2mm, 250A, 40 cm/min, シールド } \\
\hline
\end{tabular}

図 3 MAG 溶接の溶滴移行に及ほすシールドガスの影響

\section{2 ビード外観および断面}

MAG 溶接において $\mathrm{Ar}-\mathrm{CO}_{2}$ および $\mathrm{Ar}-\mathrm{O}_{2}$ 用いた場合 の各ガス濃度における溶接ビード外観および断面を図

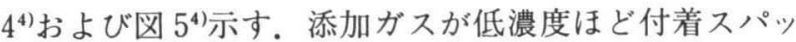
夕およU゙スラグが少なく，美しいビード外観が得られ， 高濃度の $\mathrm{CO}_{2}$ では，スパッタやスラグが多く，更にビー ド止端部もやや不揃いとなる。溶込み形状は, 添加がス が低濃度ほどややフィンガー形状となり，余盛形状は， 高濃度 $\mathrm{CO}_{2}$ においてやや凸型となる。

また，ステンレス鋼の TIG 溶接において, $\mathrm{Ar}$ と Ar-

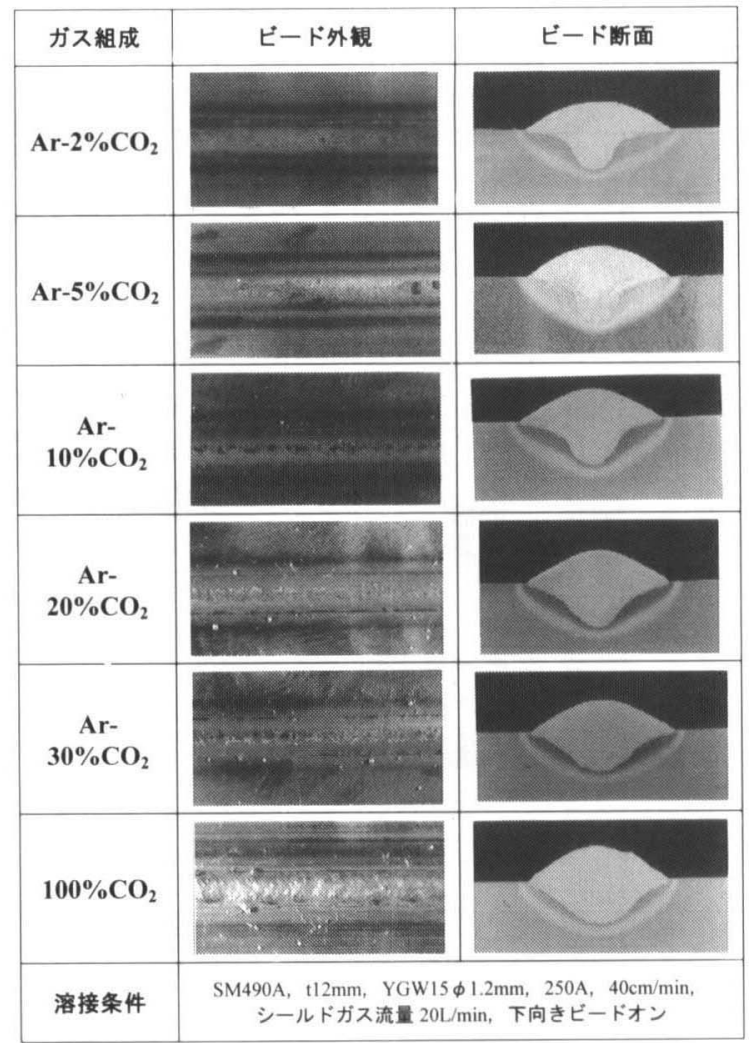

図 $4 \mathrm{Ar}-\mathrm{CO}_{2}$ 溶接ビード外観およU゙断面

\begin{tabular}{|c|c|c|}
\hline ガス組成 & ビード外钼 & ビード断面 \\
\hline Ar- $1 \% \mathrm{O}_{2}$ & $3: 2.2$ & \\
\hline Ar- $2 \% \mathrm{O}_{2}$ & 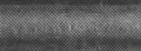 & \\
\hline $\mathrm{Ar}-3 \% \mathrm{O}_{2}$ & $a^{2}=y^{2}$ & \\
\hline $\mathrm{Ar}-5 \% \mathrm{O}_{2}$ & $2-2=0$ & \\
\hline $\mathrm{Ar}-8 \% \mathrm{O}_{2}$ & & \\
\hline 溶接条件 & $\begin{array}{r}1490 \mathrm{~A}, \mathrm{t} / 2 \mathrm{~mm}, \\
\text { シールドガス }\end{array}$ & $\begin{array}{r}250 \mathrm{~A}, 40 \mathrm{c} \\
\text { 向きビードオ }\end{array}$ \\
\hline
\end{tabular}

図 $5 \mathrm{Ar}-\mathrm{O}_{2}$ 溶接ピード外観および断面

$\mathrm{H}_{2}$ を用いた場合のビード断面を図 6 に示す. $\mathrm{H}_{2}$ の添加 により，溶込みが著しく大きくなっている。 


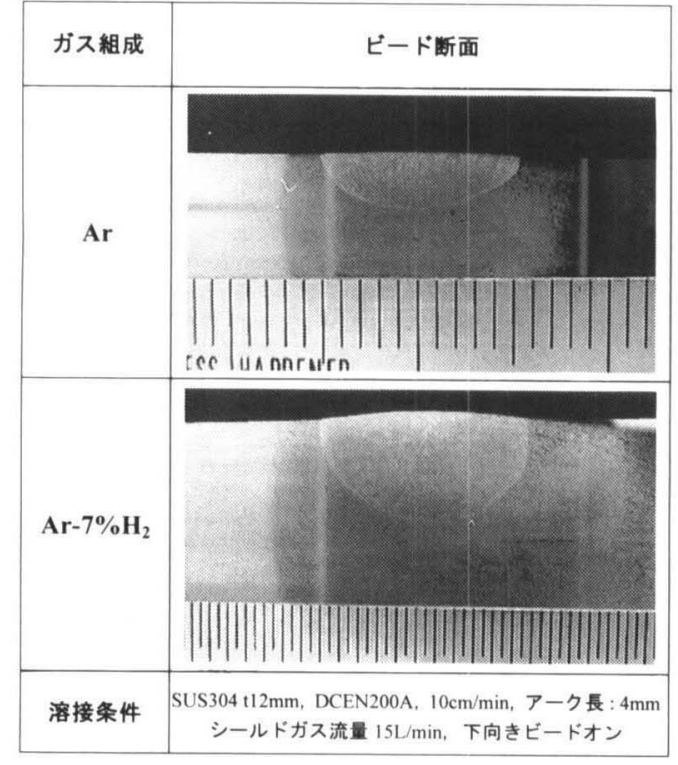

図 6 ステンレス鋼 TIG 溶接の溶込みに及ほすシールド ガスの影響

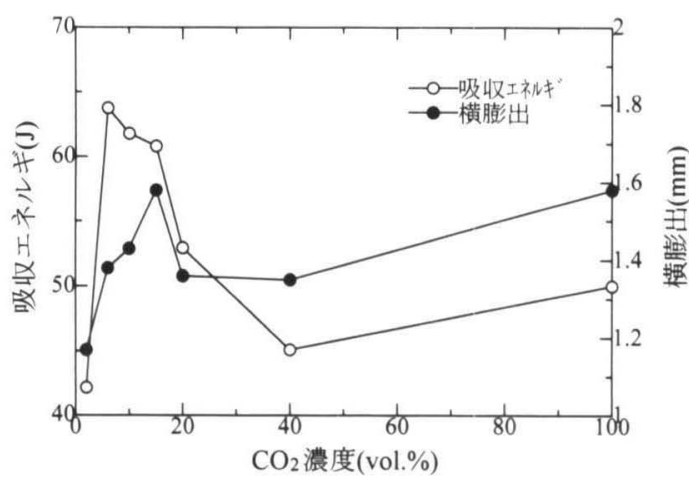

(a) $\mathrm{Ar}-\mathrm{CO}_{2}$

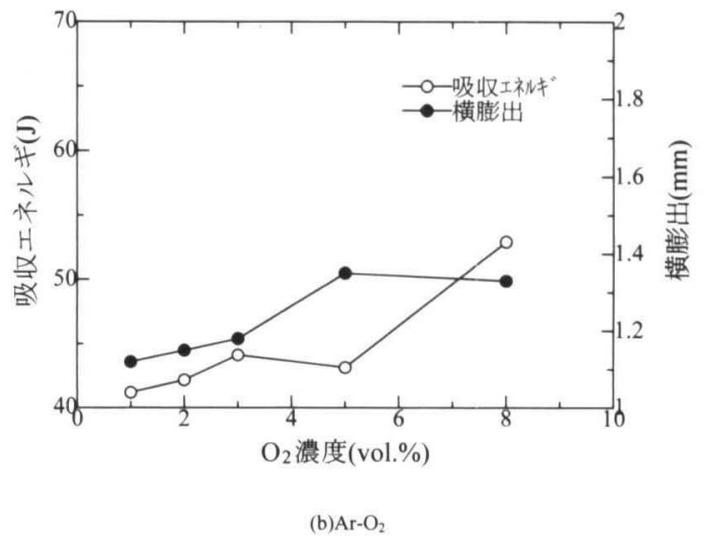

図 7 溶接金属の䩗性に及ほすシールドガスの影響 (SM $490 \mathrm{~A}, \mathrm{t} 12 \mathrm{~mm}$, YGW 15 क $1.2 \mathrm{~mm}, 300 \mathrm{~A}$, $40 \mathrm{~cm} / \mathrm{min}$, 試験温度 $-20^{\circ} \mathrm{C}$, ハーフサイズ試験片)

\section{3 溶接金属の機械的性質と化学成分}

溶接金属の機械的性質は，その化学成分によって概ね 決定されるが, シールドガスによる影響が顕著なのは, 溶接金属中の酸素と窒素成分の差異による靸性の変化で ある. MAG 溶接における $\mathrm{Ar}-\mathrm{CO}_{2}$ おび $\mathrm{Ar}-\mathrm{O}_{2}$ での溶

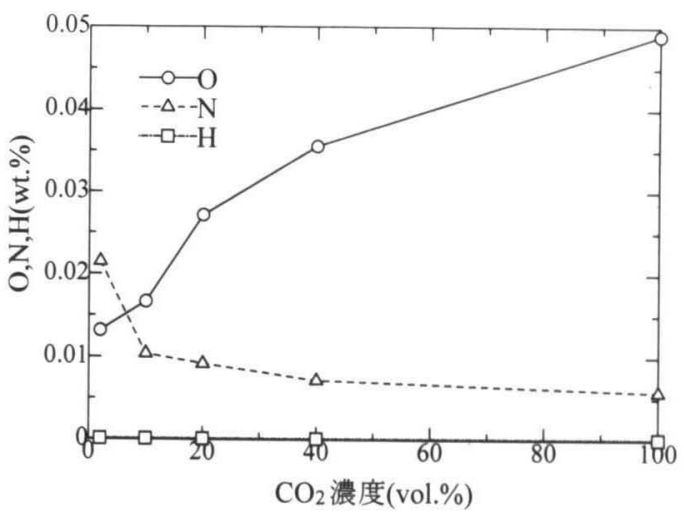

(a) $\mathrm{Ar}-\mathrm{CO}_{2}$

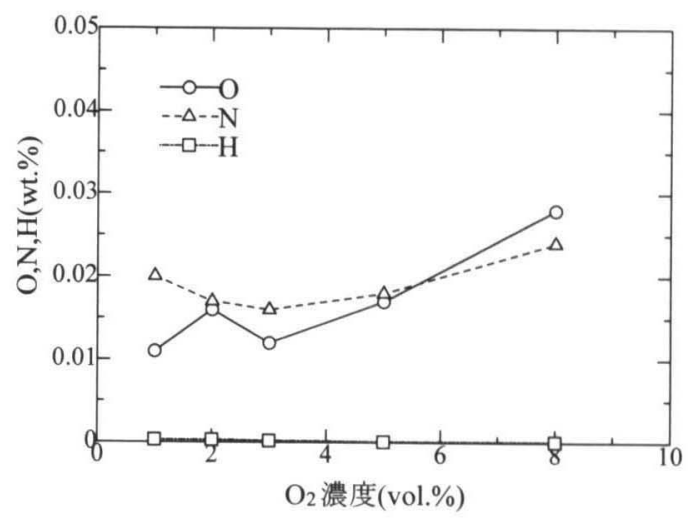

(b) $\mathrm{Ar}-\mathrm{O}_{2}$

図 8 溶接金属中のガス成分に及ほすシールドガスの影帮 (SM $490 \mathrm{~A}, \mathrm{t} 12 \mathrm{~mm}$, YGW 15 ф $1.2 \mathrm{~mm}, 250 \mathrm{~A}$, $40 \mathrm{~cm} / \mathrm{min}$ )

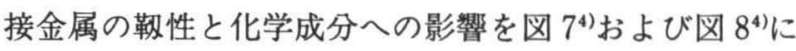
示す．各ガス濃度における靶性值と溶接金属中の酸素お よび窒素量とは相関関係が認められる。

\section{3. 溶接作業性に及ぼすシールドガスの影響}

\section{1 アークの安定性・スタート性}

MAG 溶接に純 Ar を用いると，アークが不安定で良 好な溶接ビードは得られず，アークが安定するために は，ある程度の酸化性ガスの添加が必要である。必要最 低限の添加ガス濃度は, 溶接条件(特に溶接電流)によっ ても異なるが, 一般的な条件範囲では $\mathrm{Ar}-\mathrm{CO}_{2}$ の場合, 約 $5 \% \mathrm{CO}_{2}, \mathrm{Ar}-\mathrm{O}_{2}$ の場合では，約 $2 \% \mathrm{O}_{2}$ 程度である。

また，TIG 溶接において純 $\mathrm{He}$ を用いるとアークス タート性（点弧性）が悪くなったり，ややシールド性が 劣るため, Ar との混合ガスとして利用するとよい.

\section{2 高速溶接性}

ロボット等の自動溶接においては, その溶接速度の増 大は生産性向上への寄与が大きいため, 高速溶接の実現 は現在最も重要なテーマの一つである. 困 9 にステンレ ス鋼 TIGの高速溶接性に及ぼすシールドガス組成の影 響を示すが, $\mathrm{Ar} に \mathrm{He}$ や $\mathrm{H}_{2}$ を添加することによりハン 


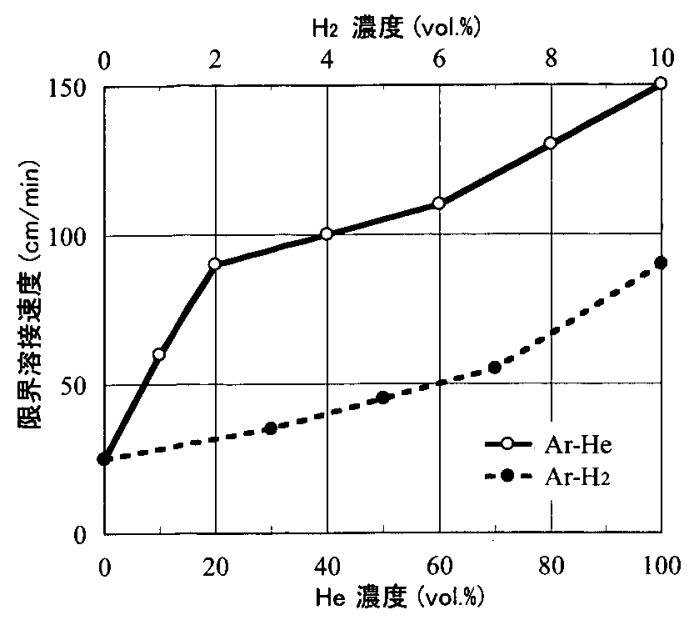

图 9 ステンレス鋼 TIG 溶接の限界速度に及ぼすシールド ガスの影響

(SUS 304, t $6 \mathrm{~mm}$, DCEN $250 \mathrm{~A}, ア ー ク$ 長 $3 \mathrm{~mm}$, 下向きビードオン)

表 1 炭素鋼 MAG 溶接において発生するCO 濃度

\begin{tabular}{|c|c|c|}
\hline ガス組成 & $\mathrm{CO}_{2}$ & $\mathrm{Ar}-20 \% \mathrm{CO}_{2}$ \\
\hline $\begin{array}{l}\text { CO 融度 } \\
(\mathrm{ppm})\end{array}$ & 915 & 260 \\
\hline 計測条件 & \multicolumn{2}{|c|}{$\begin{array}{l}\text { 計測位罚 : アーク上方 } 30 \mathrm{~cm}, \\
\text { 計測器 : ガスクロマトグラフ, } \\
\text { 電流 : } 250 \mathrm{~A}, \text { チップ母材間距離 : } 20 \mathrm{~mm}, \\
\text { ワイヤ径 : } \$ 1.2 \mathrm{~mm}, \text { ガス流量 : }: 20 \mathrm{~L} / \mathrm{min}\end{array}$} \\
\hline
\end{tabular}

ピングの起こらない限界溶接速度も増大させることがで きる。

\section{3 作業罢境}

近年, 溶接作業の安全確保の観点から, 溶接時の環境 雾囲気についても注目されつつある.溶接中に発生する 有害雾囲気濃度に及ぼすシールドガスの影響を表 1 およ び表 2 に示すが, MAG 溶接においては $\mathrm{CO}_{2}$ よりも $\mathrm{Ar}$ $\mathrm{CO}_{2}$ の方が著しく $\mathrm{CO}$ 濃度が低くなり，アルミ TIG 溶接 においては，Arを用いた場合に比べて，Ar-Heの方 がオゾン濃度が大きく低下する。

\section{4. おわりに}

以上に記載したシールドガスによる溶接品質や作業性 への影響は，ガス種固有の物理的・化学的性質によって 定まるものであり，ガスの組成や混合精度が安定してい
表 2 アルミTIG 溶接に扔いて発生するオソン濃度

\begin{tabular}{|c|c|c|}
\hline ガス組成 & Ar & Ar-50\%He \\
\hline $\begin{array}{c}\text { オソン聴度 } \\
\text { (ppm) }\end{array}$ & 2.1 & 0.59 \\
\hline 竍測条件 & \multicolumn{2}{|c|}{ 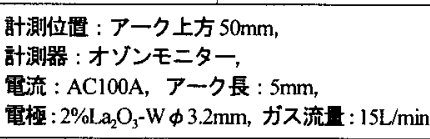 } \\
\hline
\end{tabular}

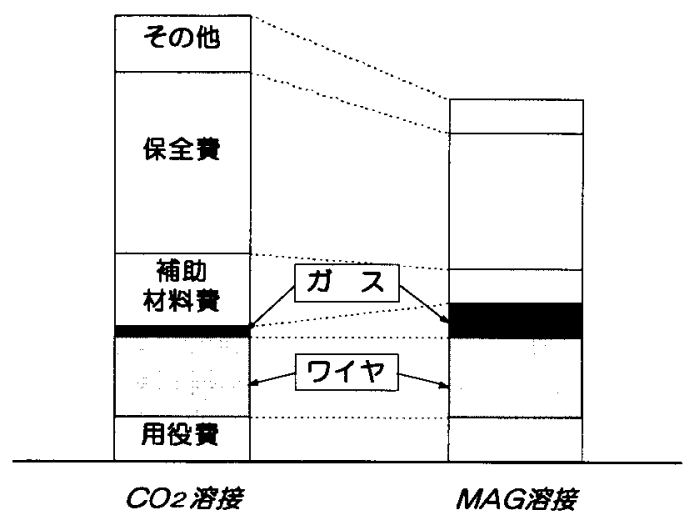

図 10 単位溶接長の設備稼動費

れば，再現性の高い効果が得られる。この点で，他の溶 接施工管理条件と比べても比較的管理しやすい項目であ ると思われ，シールドガスによる品質・作業性改善は経 済的かつ速効的なアプローチ方法であると考える。

コストについても，単純なガス単価による比較ではな く，溶接に関わる作業全体のトータルコストの低減（図 105)参照) という観点で, 最適なシールドガス種を選択す ることが, 今後のより一層のコストダウンと生産性向上 につながるものと考える.

\section{参考 文 献}

1) '99 溶接関連資料集, 溶接材料編, 過去 20 年間の溶接材料 生産, 日本溶接棒工業会、産報出版 (1999).

2）広瀨 隆：海外のマグ・ミグ溶接事情，溶接技術，Vol. 41 (1993), No. 2, p. 111-114.

3) W. Lucas: Welding \& Fabrication, June (1992), 218.

4）佐藤豊幸：マグ溶接における各種シールドガスの特性, 溶 接技術, Vol. 46 (1998), No. 6, p. 131-139.

5）松井仁志：自動車分野における短時間，低コスト，適正品 質組立技術の展開，日本学術会議接合工学䙳門委員会平成 11 年度溶接シンポジウム, p. 10. 